\title{
NEW LIFE FROM A PASTORAL TEXT OF TERROR? GENDER PERSPECTIVES ON GOD AND HUMANITY IN 1 TIMOTHY $2^{1}$
}

\author{
Elna Mouton \\ Old and New Testament \\ Stellenbosch University \\ Ellen van Wolde \\ Source Texts of Judaism and Christianity \\ Radboud University of Nijmegen
}

\begin{abstract}
Amidst threatening pseudo-practices, 1 Timothy seems to be concerned mainly with the integrity of the Christian gospel within the larger Greco-Roman society. To account for its rich yet complex world view, the intertextual coherence of 1 Tim 1:15-3:1 is investigated - with special reference to gender images from Gen 2-3 in 1 Tim 2:13-15. In an attempt to make sense of the utterances regarding women in 2:8-15, and particularly the explanation in 2:13-15, the essay explores two main sets of arguments. A first view explores the implications of a literal interpretation of 1 Tim 2:13-15. It argues that the author contrasted the thinking of Gen 2-3 by importing a limited selection from it into his letter - a strategy bearing the risk of being incompatible with the theological thrust of both 1 Tim and Gen 1-3. A second view argues that 1 Tim 2:13-15 served as an allegory, and that Adam and Eve, as well as the image of childbearing, functioned metaphorically as motivation for moral behaviour. The essay concludes that 1 Tim 2:8-15 is a context-specific appropriation of the creation story rather than a universal statement on the relationship between women and men. It pleads for a life-giving rhetoric that either uses 1 Timothy's theological thrust as a lens for interpreting 2:8-15 or accepts (some aspects of) it as irretrievably patriarchal and violent, yet allowing it to function as a mirror for on-going discussions on human dignity and the integrity of creation.
\end{abstract}

Key Words: Theological Thrust of 1 Tim, Gender Images of God and Humanity, Socio-Cultural-Ecclesial Context, Genesis 1-3, Life-Giving Rhetoric

For many people, 1 Timothy 2:8-15 is a canonical text that resists being read liberatively. It has probably become - especially since the nineteenth century - one of the most controversial texts from within the history of biblical interpretation relating to the participation of women in church leadership and decision-making processes (Johnson 2001:42-54; Wall 2004:82). It often functioned explicitly or implicitly, and in various ecclesial contexts still

An expanded version of a paper, "Saved through childbearing? Perspectives on God and humanity in 1 Tim (1:15-3:1)", read at the annual meeting of the AAR/SBL, San Antonio, 20-23 Nov 2004. A shorter version was published as a chapter in a book titled Men in the Pulpit, Women in the Pew? Addressing gender inequality in Africa (eds. Hendriks, HJ et al). Stellenbosch: SUN MeDIA (2012). Cf. also Mouton 2006; Van Wolde 2006. The 'text of terror' in the title is borrowed from Phyllis Trible's 1984 monograph. Its combination with 'pastoral' forms an oxymoron. 
functions, to legitimate private, submissive and restrictive positions for women. ${ }^{2}$ The essay asserts that, if the situation is to be curbed at all, any form of stereotyping - especially gender inequality as a deeply entrenched cultural and religious phenomenon - has to be addressed in nuanced and dignifying ways. Because the interpretation of 1 Timothy 2 has often contributed to an ethos where not only the prophetic contribution of women, but also their humanity and growth as baptised members of God's household, has been inhibited or viewed as inferior, its appropriation by later generations puts the integrity of the Christian gospel at stake.

The essay has a twofold purpose. Its first aim is a brief analysis of 1 Timothy 2:8-15 within the broad literary thrust of the epistle. Its second aim is to explore the intertextual coherence of the passage, with special reference to gender images from Genesis 2-3 referred to in 2:13-15. Both literal and allegorical approaches to the latter will be investigated.

\section{Theological Thrust of 1 Timothy}

As a point of departure, the theological thrust of the epistle is identified - particularly as rhetorical response to the opposition that the author and his co-workers faced at Ephesus.

1 Timothy is undergirded by (re-interpreted male) images of God as a gracious saviour through Christ Jesus ( $\sigma \omega \tau \hat{\eta} \rho-1: 1,13-16 ; 2: 3-6 ; 4: 10 ; 2$ Tim 1:9-10), an honourable father

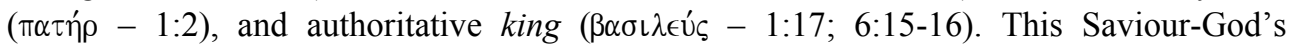
$\sigma \omega \tau \eta i^{i} \alpha$ (encompassing kingdom of health and goodwill) is compared to a transformed

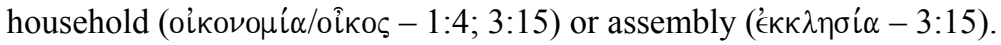

In order to focus on 2:8-15 from here on, it is necessary to situate the passage within its

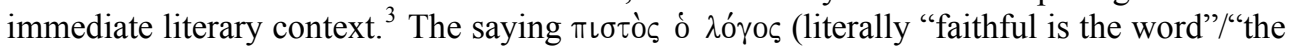
saying is sure" - NRSV/"This is a reliable opinion" - Johnson 2001:198) recurs in 1:15 and $3: 1$, possibly presenting itself as a framing device for demarcating 1:15-3:1 as a coherent syntactic and semantic unit. ${ }^{4}$ The section comprises a saying about Jesus the saviour of the world (1:15-16), a doxology (1:17), encouragement to Timothy (1:18-20), and instructions on prayer and worship (2:1-15), with specific reference to God as $\sigma \omega \tau \hat{\eta} \rho$ in 2:3-4. It ends with a second saying about salvation, namely that a woman would be saved through

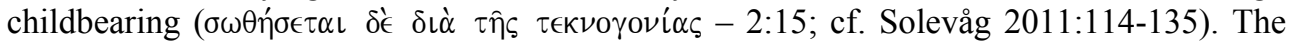
focus subject of 1:15-3:1, therefore, is the believers' appropriate response to God's radical saving initiative in Christ Jesus. Every other aspect constitutes the predicate which makes an extended assertion about the subject.

The two main sentences in chapter 2 are introduced by П $\alpha \rho \alpha \kappa \alpha \lambda \hat{\omega}$ oûv (I exhort,

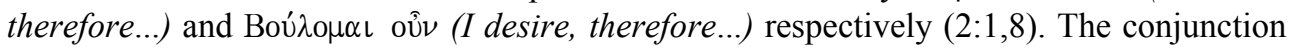
oûv links what follows as a direct and logical consequence to the preceding sections and purpose for writing $(1: 3-7,15)$, and as an explication of the glorious and truthful gospel of

For the history of interpretation of 1 Tim 2:8-15, see Roloff 1988:142-147; Porter 1993:87-90; Schottroff 1995:69-78; Desjardins 1997:99-100; Schüssler Fiorenza 1999:1-2; Bassler 2000:1137-1141; Phiri 2000:267293; Johnson 2001:20-54; Kawale 2001a:211-223; Kawale 2001b:225-238; Jacobs 2002:112-133; Scholer 2003; Wall 2004:81-82; West 2004:160-165; Waters 2004:731-733; Oguntoyinbo-Atere 2011. Cf. also n.22 and 36 .

3 See Addendum A for a broad discourse analysis of the NA27/UBS4 text of 1 Tim 1:15-3:1.

4 The "sayings" in 1 Tim (also 4:9) are all statements concerning salvation (Johnson 2001:203, with reference to Nestle-Aland; cf. Solevåg 2011:95). For this reason 3:1 fits the context of 2:15 better, and is interpreted here as a comment on 2:15 and as a conclusion to ch 2 rather than an introduction to ch 3 , as suggested by most translations. 


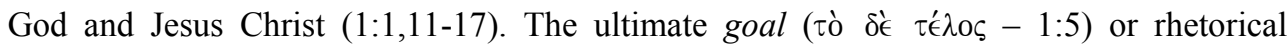
purpose of the author's instruction is the community's appropriate response to this gospel, namely an ethos of "love that comes from a pure heart, a good conscience, and sincere faith" (NRSV). ${ }^{5}$ This gospel has been entrusted to the author's care, referred to as Paul (1:1-16), who now shares the responsibility with Timothy, his "true son in the faith" $(1: 2,18-19 ; 4: 11-16 ; 6: 20)$. Through Timothy the author urges the believing community in

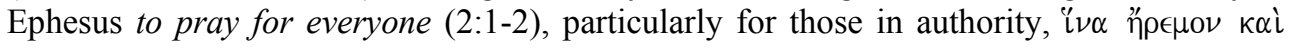

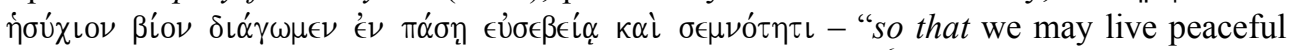
and quiet lives in all 'godliness' (NIV) and 'dignity", (NRSV). ${ }^{6}$

Two theological motivations are given for Timothy's call to service and the community's ethos of public worship: (a) There is only one God and one mediator between God and humanity, Christ Jesus $(1: 17 ; 2: 5)$; (b) it is good, and pleases God that all people be saved and live worthy, godly lives $(1: 15 ; 2: 3-6){ }^{7}$ These theological references - articulated in limited human language - represent the dynamic thrust and orientation of the epistle. It concerns the recipients' primary identity as the household of God $(1: 4 ; 3: 15){ }^{8}$

Verses 2:8-15 take the invitation to prayer in 2:1-2 further by emphasising the kind of disposition, atmosphere and even clothing that would be conducive for truthful worship, and worthy of respect (cf. 3:1-15). The author's first wish is that men should pray in every place, "lifting up holy hands without anger or argument" (2:8). Likewise, women should pray, having dressed themselves "modestly and decently in suitable clothing ... with good works" (2:9-10). ${ }^{9}$ Subsequent to the theological motivations in 1:15-2:7, two anthropological reasons are provided in 2:8-15 to support the instructions for worthy behaviour in the worship service, particularly regarding women: (a) Adam was formed first, then Eve;

These notions run like a golden thread through the entire epistle (cf. $1: 14,19 ; 2: 2,7-8,15 ; 3: 2,9,13 ; 4: 1,6-12$; $5: 7-8,22 ; 6: 1-2,11,14,21)$.

6 Syntactically, prayer is the main subject of chapter 2 (cf. Addendum A; 4:4-5; 5:5).

7 Emphasis on the one and only God in 1 Tim seems not only to occur over against the divisions from within the faith community, but also the polytheism of their neighbours - cf. the shema of Deut 6:4 ("Hear, o Israel: The Lord is our God, the Lord alone"). God is described as o $\sigma \omega \tau \hat{\rho} \rho$, the saviour of all human beings (1:1,15; $2: 3,4 ; 4: 10)$ - not only the saviour from sin as any form of alienation within and among themselves or between them and God $(1: 15 ; 2: 14 ; 5: 20,22)$, but also the saviour towards a new life in Christ $(2: 2)$. Trustworthy knowledge of this life-giving God (4:10;6:13) is implicitly defined as saving (liberating and healing) knowledge. Jesus Christ is likewise pictured in dramatic images such as "our hope" ( $\dot{\eta} \dot{\epsilon} \lambda \pi \iota \varsigma \dot{\eta} \mu \omega \hat{\omega}-1: 1$; cf. $4: 9 ; 5: 5 ; 6: 17$ ), and in 2:3-6 as the only mediator (o $\mu \in \sigma i \tau \eta \varsigma$ ) between God and humanity, who gave himself as

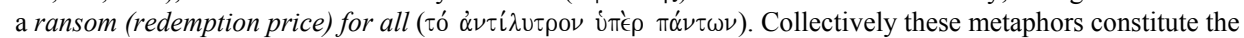
letter's theological thrust, implicitly and explicitly subverting any form of deception or division in and among the recipients.

8 In view of this logic, the essay works with the theological premise that 1 Tim 2 primarily has a redemptive, non-dominating, justice-seeking orientation, and that the meaning and rhetorical effect of its 'authority' need to be interpreted and claimed from this perspective (cf. Schottroff 1995:124; Horrell 2001:306-311). Because of the publicly androcentric and patriarchal socio-cultural contexts from within which these images originated (and the concomitant risk of using them in other contexts), this premise needs, however, to be assessed critically during the exegetical process. (For the broad socio-cultural context of the NT, and Jewish, GrecoRoman, and Christian language of kinship and household in particular, see Meeks 1983:23-25, 53-55, 75-77; 1993:1-17, 109-110; Brooten 1986; Jacobs 2002:123-128; Ferguson 2003:68-80, 427-430; Osiek 1996:8-24; 2005; Sanders 2002:117-123; Solevåg 2011:51-53, 99-114, 239-240).

9 Typically, the passage reflects the desired ethos mentioned in 1:5 and 2:2, and particularly in the conditional

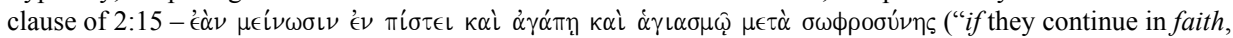
love and holiness with propriety" - NIV). The latter may also be translated with 'sobriety', 'modesty' or 'discernment' (cf. 2:9). The desired outcomes of godliness, holiness, faith and love referred to in 2:2 and 15 thus frame the instructions on worship in chapter 2 (within the broader context of the author's explicit goal in $1: 5$ and $3: 14-15)$. 
and (b) Adam was not deceived but the woman was (vv 13-14). ${ }^{10}$ Then the argument turns to yet another utterance on salvation in $2: 15 .{ }^{11}$

Before dealing with the complex interpretation of Genesis 2-3 in 2:13-14, the probable moral situation from within which the document originated, is briefly explored.

\section{Timothy's Exigence?}

The so-called Pastoral epistles ( 1 and 2 Timothy, Titus) are addressed to the pastors of early faith communities in Asia Minor. According to 1 Timothy 1:3, this epistle was written to Timothy while he was in Ephesus, where Paul probably left him to do follow-up work after they had ministered there for some time during his third missionary journey. ${ }^{12}$ Opinions vary, however, when it comes to situating 1 Timothy in terms of time, authorship and circumstance. ${ }^{13}$

The exigence (urgent need) prompting the author seems to be his concern with preserving the sound teaching and ethos of the Christian faith against various pseudo-practices which apparently threatened it (Scholer 2003:100-105). The text mentions certain opponents or false teachers in the Christian community at Ephesus (1:3-11), although they are not clearly identified. Later readers are left with fragments of their influence, together with the author's passionate response to it. ${ }^{14} \mathrm{He}$ is concerned that the recipients will be

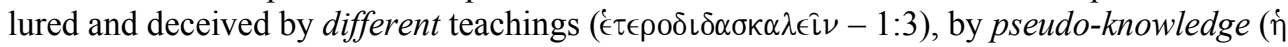
$\psi \in \cup \delta \omega \nu u^{\prime} \eta \eta \gamma \nu \omega ́ \sigma\llcorner\varsigma-6: 20-21)$, and consequently drawn into endless controversy, dispute, speculation, suspicion and confusion which could easily bereave them of their freedom, love and truth in Jesus Christ $(1: 4 ; 2: 8 ; 3: 2-3 ; 4: 2 ; 6: 3,20-21) .{ }^{15}$ He interprets the false

10 It is typical of the undisputed Pauline letters that a verb or idea of command or prohibition is followed by $\gamma \grave{\alpha} \rho$ in a causal sense (Bowman 1992:149, 203).

11 The salvation rhetoric used here is not uncommon in the rest of the letter as well as the NT. In 1 Tim 4:16 the author instructs Timothy to pay close attention to himself and to his teaching, "for in doing this you will save both yourself and your hearers" (NRSV; cf. Solevåg 2011:95-99; Mk 13:13; Mt 24:13; Lk 21:19).

12 Cf. Acts 18:23-20:38; Kroeger \& Kroeger 1992:47-58; Mounce 2000:xlviii-lix, lxiv-lxix.

13 Some scholars believe it pertains to a situation in Ephesus during the early sixties of the first century (Pelser 1984:190), while others understand it to be a deutero-Pauline (even second century) writing (Dewey 1998:444-449), in which case the name 'Paul' could have served as a rhetorical device. For detailed discussions on introductory issues regarding 1 Tim, see Roloff 1988:19-50; Mounce 2000:cxviii-cxxix; Johnson 2001:13-15, 55-99.

14 The author's pathos for the trustworthiness of the saving grace of Christ is expressed in recurring confessional statements such as "The saying is sure and worthy of full acceptance, that Christ Jesus came into the world to

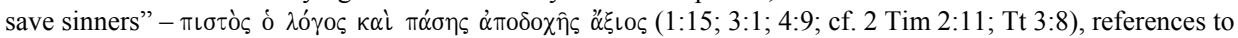
"knowledge of the truth" $-\dot{\eta} \dot{\epsilon} \pi i \gamma \nu \omega \sigma \iota \varsigma \dot{\alpha} \lambda \eta \theta \epsilon i \alpha \zeta(2: 4 ; 4: 3)$, as well as purpose statements at the beginning

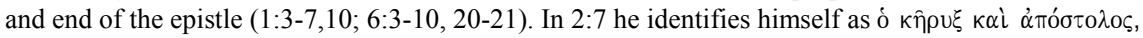

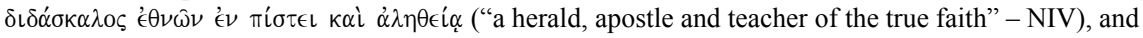

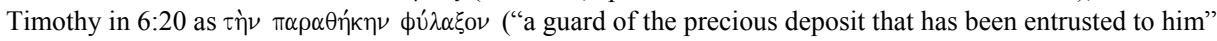

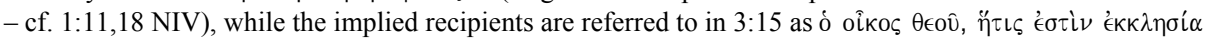

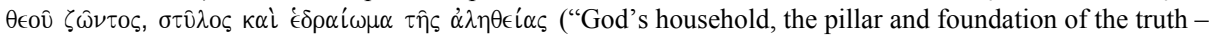
NIV"/"bulwark of the truth" - NRSV).

15 The exact nature of such false teachings is particularly pertinent as context for 2:8-15. Also this issue has led to much debate in the past (cf. Pelser 1984:188-189; Gritz 1991:31-49; Kroeger \& Kroeger 1992:59-66; Mounce 2000:lxix-lxxiv; Johnson 2001:142-154). Reference to controversy about genealogies and the Torah (1:4-10; cf. Tt 1:10,14; 3:9) may suggest a Jewish character, which concern the very heart of a Jewish identity. Reference to myths, genealogies $(1: 4 ; 4: 7 ; 6: 20)$ and so-called knowledge $(6: 20-21)$ may suggest association with some form of Gnosticism (Bassler 2000:1137). Reference to stories told by old women and the asceticism of celibacy and abstinence from foods (4:2-7; Tt 1:14-16) may suggest ascetic Christian groups, which often included women as prominent members (2 Tim 3:6-9; 1 Tim 5:11-16; cf. Dewey 1998:445; Brown 1992:57, 77-94; contra Solevåg 2011:91-94, 134-135). In the atmosphere of Hellenism it is also possible that elements of Greek dualism were appropriated with its negative view of the body and all things 
teachings as a characteristic of 'later times' in which "some will renounce the faith by paying attention to deceitful spirits and teaching of demons" (4:1 - NRSV; cf. 1:19-20). This may further explain the epistle's urgency and the author's serious exhortations to believers not to deviate from their focus on God and Christ Jesus $(1: 17 ; 2: 3-6 ; 4: 16 ; 5: 21$; 6:13-15). In view of this 'state of emergency', the author instructs them to avoid any argument or disposition that could result in divisive quarrels and the consequent loss of their moral discernment and integrity.

Metaphorical descriptions of God and the implied recipients' moral identity and conduct thus seem to be embedded within a rhetorical context of unholy disharmony, disputes, and quarrels. Ultimately, every moral exhortation - including 2:8-15 - derives its relevance and 'authority' from its theological emphasis, as response to a particular exigence. ${ }^{16}$ Because of

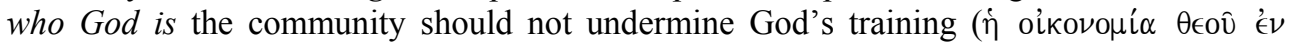
$\pi i$ i $\tau \in \mathrm{L}-1: 4)$. Because of who God is they are invited to respond in reverence and awe, and with 'good works' (2:9-10; 5:10,25; 6:18). Because of God's desire that all people be saved (1:15), the author wishes to ensure proper conduct in the worship assembly - particularly in view of the distortion and divisions caused by false teachings. ${ }^{17}$

It is from within this rich yet complex theological-ethical vision that we believe the coherence of 1 Timothy 1:15-3:1 should be explored. Further exegetical observations will now be made, particularly in view of 2:8-15.

\section{Praying Without Anger ... Clothed in Good Works}

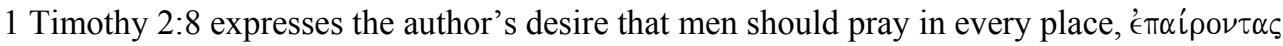

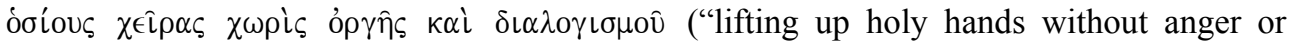
argument" - NRSV, literally without wrath, doubting or dissension). Noteworthy is that believing men are encouraged to take special care to avoid disputing or a quarrelsome spirit at their prayer meetings (everywhere), so as to cause no further division and conflict (Bowman 1992:196). This qualification is confirmed by other moral instructions in the epistle - all meant to contribute towards a peaceful, holy and trustworthy way of living in God's sight.

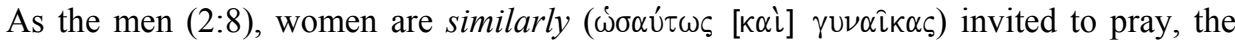
latter by implication (2:9). Since most synagogue prayers were offered by men, this freedom seems significant (Keener 1992:102-103). The recurring conjunction $\dot{\omega} \sigma \alpha \dot{\tau} \tau \omega \varsigma$ communicates a sense of mutuality, partnership and interconnectedness among the members of the community $(3: 8,11$; cf. $5: 25)$. When the focus turns to women, however, specific attention is given to the manner in which they should dress when they pray in public. Maybe different reasons for concern (regarding the participation of men and

material (Wiebe 1994:56). This may account for the author's obsession with 'good deeds' (2:10; 5:10,25; 6:18), which are substantiated by practical, bodily actions of loving service and compassion (such as bearing and bringing up children, being hospitable, washing the feet of the saints, helping those in trouble, teaching truthfully $-5: 10 ; 4: 11-13$ ). Continuous references to 'good works' indicate that it is "not a trivializing phrase, but points to a life of productive virtue" (Johnson 2001:200). In the final analysis the great "mystery of godliness", according to 1 Tim 3:16, is described significantly in bodily terms: "God appeared in a body" (NIV), "God was revealed in flesh" (NRSV).

16 Cf. Donelson 1988:108-113 for a similar discussion on the logic and coherence of ethical reasoning in the Pastorals, and the functioning of enthymeme in particular.

17 In the worship service men and women should therefore pray in a specific manner (2:1-3, 8-9). The overseers should therefore be "above reproach" (3:2). Deacons and their wives (sic) should therefore be "worthy of respect" (3:8,11 - NIV). Timothy himself was therefore to set a truthful example of sound living and teaching, "without spot or blame" (4:6-16; 5:22; 6:14). 
women) prompted the author to address the issue of proper worship in this nuanced way. Some of the probable reasons for the admonitions to women deserve closer attention.

Firstly, the insistence that women dress modestly and perform good deeds "is a commonplace in both Greco-Roman and Jewish moralists" (Johnson 2001:199; cf. Keener 1992:103-107; Scholer 2003:105-106). ${ }^{18}$ Rather than making a sensational display of excessive outer adornment in the form of dress, fancy hair styles or jewellery, thereby distracting the attention at worship meetings, believing women were to be clothed "with good works, as is proper for women who profess reverence for God" (2:9-10 - NRSV).

Secondly, the women described in verses 9-10 suggest wealthy, educated and articulate women (Cotter 1994:357-358; Osiek 2005:212; Solevåg 2011:119). Although Paul's converts and co-workers also included wealthy women (Acts 16:15; 17:4,12,34), the rhetoric of 1 Timothy suggests a certain unhealthy love of money, which is contrasted to their hope in God and the treasure of 'good deeds' $(3: 3 ; 6: 6-10,17-19)$. The rest of the passage (2:11-15) substantiates the nature of such 'good works' for women in the specific socioreligious context implied by the text.

\section{Let a Woman Learn...!}

The 'good deeds' of 2:10 are explicated in terms of four distinct elements with respect to the functioning of women, comprising:

- a positive statement in 2:11 concerning women's learning;

- a negative statement: women are not permitted to teach or exercise authority over men (v 12);

- a motivating reason: the example of Adam and Eve (13-14); and

- a concluding remark on women being saved through childbearing (2:15-3:1).

As the very first explication of the 'good deeds' referred to in verse 10, verse 11 starts with a remarkable statement, while the tone seems to change from (more gentle?) persuasion to command: $\gamma \nu \nu \grave{\eta}$... $\mu \alpha \nu \theta \alpha \nu \nu^{\prime} \tau \omega$ ("Let a woman learn..."). This is a radical movement from within the cultural context of Judaism where men were the public speakers in any assembly, and where it was forbidden that women should learn and interpret the Torah (Johnson 2001:201,204). ${ }^{19}$

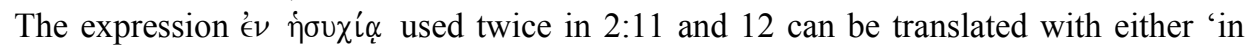
silence' (NRSV) or 'in quietness' (NIV). In 2:2 joúx เov ßíov is usually translated with 'a quiet life'. In the socio-rhetorical context of 1 Timothy, the invitation to 'quietness' and 'full submission' would have represented a respectful, honourable attitude for proper learning, spiritual contemplation, and receptivity. ${ }^{20}$ Moreover, the epistle often contrasts a 'modest' and 'submissive' attitude $(2: 9,11)$ to conceit and arrogance (cf. 3:6; 6:4).

18 In both Hellenistic and Jewish thought the connection between certain types of dress and improper sexual conduct on the part of women was prominent. The fact that the early Christian community at Ephesus had to redefine its identity and ethos amidst various mother and saviour goddess cults - such as the Artemis fertility cult - probably further accounts for the particular nature of these admonitions. See Kroeger \& Kroeger 1992:67-74, 105-113, 153-170 for a discussion on (female) deities and mediators in Ephesus during the first century CE (cf. also Acts 19:27-35; Gritz 1991:36-43; Waters 2004:725-727). Similar instructions in 1 Pt 3:17 imply that this could have been an issue of a more general nature.

19 Cf. Barnett 1989:229: "In the Talmud is written: "may the words of the Torah be burned rather than be handed over to a woman' ... Women were not even permitted to say the Benediction after a meal ... That Christian women were encouraged to learn was a new departure."

20 Cf. Keener 1992:107-108; Bowman 1992:199; Kroeger \& Kroeger 1992:74-76; Wiebe 1994:58,62; Barnett 1989:229-230; Wall 2004:86-91. According to Malina (1993:39,51), an honourable person in the first-century Mediterranean world would have been "one who knows how to and can maintain his or her social boundaries 


\section{... But I do not Permit Her to Teach}

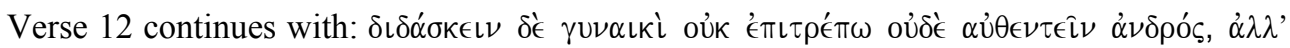

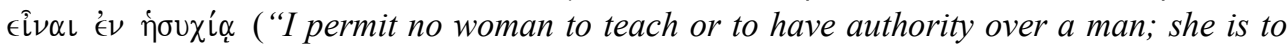
keep silent" - NRSV). The command that women should not teach occurs only here in the New Testament, and probably has to be understood in the light of the fundamental issue that is addressed throughout 1 Timothy, namely the false teachings that plagued the Christian community in Ephesus. ${ }^{21}$ In the context of 1 Timothy, the call is probably not for a prohibition of all (female) speaking as such, but rather of speech that interrupts and disturbs. Such a disposition of 'quietness' would be in contrast to the anger and disputes that some men were bringing to the worship meetings $(2: 8){ }^{22}$

Also the Greek word $\alpha \dot{U} \theta \in \nu \tau \in \hat{\imath} \nu$ in verse 12 (to domineer or usurp authority) appears only here in the New Testament. Compared to the rare instances of its contemporary classical use, it has a substantially negative connotation, namely to act aggressively or violently against another, or to instigate forceful action or perpetrate a crime against others, leading to disruptive behaviour. ${ }^{23}$ With reference to appropriate teaching and authority, the New Testament regularly uses ${ }^{\prime} \xi_{\text {ovo }} i^{\prime} \alpha$. In the specific context of 1 Timothy, the call could have been directed "against women involved in false teaching who have abused proper exercise of authority in the church" (Scholer 2003:109). The qualification "in silence' could also have referred to a practical situation where women did not have the authority $\left({ }^{\prime} \xi \xi 0 \cup \sigma i \alpha\right)$ to speak yet, since they had not yet learned to do so (v 11). ${ }^{24}$ In the

in the intersection of power, gender, and social respect, including God. The shameless person is one who does not observe social boundaries ... one outside the boundaries of acceptable moral life, hence a person who must be denied the normal social courtesies." Therefore, "any physical boundary-crossing on the part of another presumes and implies the intention to dishonour. In honour societies, actions are more important than words, and how one speaks is more important than what one says" (Malina 1993:41; cf. the noun $\pi \alpha \rho \alpha ́ \beta \alpha \sigma \iota \varsigma$ in 2:14 which literally means "crossing of boundaries" - Johnson 2001:201). For a detailed discussion on honour and shame as pivotal values in such societies, see Malina 1993:28-55.

21 "This false teaching and its teachers had women as a particular focus and encouraged them to radically violate appropriate and honourable behaviour patterns for women" (Scholer 2003:107; cf. Solevåg 2011:121-124). Apart from specific tensions in the church at Ephesus which could have prompted such an utterance, later readers should be mindful of more general attitudes about women's public behaviour in antiquity (cf., among others, Gritz 1991:11-29, 59-73; Cotter 1994:358-372; Kittredge 1998:37-51; Scholer 2003:107-111; Osiek 2005).

22 During its history of reception, however, the unnuanced silencing of women more often and ironically served as a filter through which the rest of the text was viewed. It seems that the situationally conditioned clause "I am not allowing a woman to teach" in 2:12 (with the present indicative form of the verb, and probably referring to a specific situation in Ephesus at the time - cf. 1:7), has been interpreted as a forceful universal command, even to the detriment of the utterance "Let her learn" in 2:11 (Keener 1992:112,128 n.94). Moreover more attention seems to have been focused on the (second) negative statement in 2:11 ("in silence with full submission") than on the (first) positive one (with ironic reference to v 13!). In our view, this way of appropriating the text testifies contrarily to 1 Timothy's fundamental perspective on a life-giving God, and the church as God's life-giving household.

Although the command that women should not teach occurs only here in the NT, the text inadvertently reinforced the conservative tendencies of other utterances associated with Paul such as 1 Cor 14:33-40 and Eph 5:21-6:9, while obscuring the more liberating aspects of Paul's statements about women (cf. Bassler 2000; Schneiders 1995:349-355; Mouton 2011:275-292). Consequently, women were silenced and marginalised in churches and societies - in explicit and subtle ways - while their submissive (passive, private) role was overemphasised (cf. Phiri 2000; Kawale 2001b). In this way the context-specific utterances of 1 Tim 2:8-15 have been amplified and solidified into universal norms for ecclesial ethos and gender identity. Wiebe 1994:59; Bowman 1992:201-202; Kroeger \& Kroeger 1992:79-104, 185-188.

24 Analogously, it is stated in 3:2,6 about an overseer that he (sic) "must be an apt teacher... he must not be a recent convert, or he may be puffed up with conceit and fall into the condemnation of the devil" (NRSV; cf. 1:7 and Mk 8:29-30 regarding Jesus' "silencing" of Peter). 
broader context of 1 Timothy, any aggressive or violent action (also with regard to Paul's own background - cf. Acts 7:58-8:3; 9:1-2) is contrasted to the Christian ethos of love and peace $(1: 13 ; 2: 2 ; 3: 3)$.

For later readers of this text it would be imperative to problematise and nuance the dualistic (patriarchal) epistemology on which households and societies of the first and second century Mediterranean world were based (Meeks 1983:75-77). The hermeneutical question then becomes: Were the (general and specific) positions of men, women, children and slaves supposed to be reconstructed by early Christian rhetoric (as a redescription of patriarchal traditions from a Christian perspective)? Or was it (and specifically the rhetoric of 1 Timothy 2) a mere description of the status quo at the time, and a further legitimation of women's silent and submissive roles (Cotter 1994)? If the former was supposed to be true of 1 Timothy 2, how would its author have anticipated transcending the socio-cultural boundaries of his audience? However, if 1 Timothy 2 was a mere reflection of the status $q u o$, its 'authority' becomes a different matter for later readers. ${ }^{25}$

In a first exploratory section we would like to argue that, while the requirement that women be silent/submissive derives from Hellenistic household traditions (Bassler 2000:1139), it is re-appropriated here within the rhetoric of the (dynamic tension of the) household of God. Through his profoundly theological orientation, as argued above, the author of 1 Timothy creates a particular frame of reference, with glimpses of an alternative moral world to be inhabited by his audience. Yet, even though he seems to challenge usual assumptions about what would be regarded as 'honourable' (cf. 2:11), he remains a product of his time who could only describe the reality of God's saving presence in limited (patriarchal) language. This seems to become particularly evident in his interpretation of the creation story in 2:13-15.

\section{For Adam was formed First, and was not deceived...}

In order (for twenty-first century readers) to make sense of 1 Timothy's reference to Genesis 2-3, attention will be paid to the text's 'mode of cognition', that is, its way of thinking or constructing usable meaning from a text by importing it into another text. Carol Newsom (2006:215-233) wrote some interesting observations on the similar phenomenon of the historical résumé. One of the significant features, she said, is that it is generally assumed that the audience already knows the material. Thus the telling of the text "does not serve to convey information. Indeed, much more is known than can be put into any particular version of the story. The cognitive power of a narrative citation is rather to construct and convey significance." Hence, to repeat an element of Genesis 2-3 in 1 Timothy's letter, is to establish certain criteria of relevance: How much and which of that which everyone in the intended audience knows, belong in the Genesis story and which do not? This question will be answered firstly by a rough sketch of the Genesis text, and secondly by a study of 1 Timothy's selection from Genesis 2-3 and its mode of cognition.

The Story of Paradise or Eden Narrative in Genesis 2-3 consists of a series of subsequent narrative scenes. ${ }^{26}$ Starting with the creation of humankind (2:5-7), the planting

25 For people on the African continent, e.g., the 'authority' of Scripture has often become synonymous with 'authoritarianism' - the close association of religious (sacred) authority and the abuse of (political) power (Bediako 2000:97-107). This is particularly pertinent in the case of women and children (cf. Kanyoro \& Njoroge 1996). In continuation with Jesus' 'desacralisation' of all worldly power (which he calls the "essential thrust of the New Testament"), Bediako pleads for the desacralisation of any dominating, absolutising, manipulative authority, power, institution or structure that rules over human existence (Bediako 2000:102-107; cf. Oduyoye 2002:90-101).

26 Genesis 2-3 is called Eden Story by Stordalen 2000 and Eden Narrative by Mettinger 2007. 
of the garden in Eden, the location of the human there, and God's prohibition to eat from the tree of knowledge (2:8-17), it continues with the creation of animals $(2: 18-20)$ and the creation of the woman (2:21-25). The dramatic events take a turn in chapter 3 when the naked humans eat from the tree of knowledge and gain insight (3:1-7), upon which God conducts a hearing (3:8-13) and issues sentences (3:14-19). After an interplay of clothing (3:20-21), God expels the couple from the garden and the tree of life (3:22-24) ${ }^{27}$ In order to decide what its main plot is, the various plot segments need to be acknowledged. These segments include the human tiller of the earth or soil (especially in the framework of $2: 5,8,15 ; 3: 17-24),{ }^{28}$ the creation of humankind and the origin of its procreative competence and of its mortality, ${ }^{29}$ the divine prohibition, by some interpreted as a test of obedience, ${ }^{30}$ and the transgression of this prohibition or failure of the test.

The major theme of life and death in Genesis 2-3 is described in close relation to the tree of life. At the beginning of the story the human being was given life and allowed to eat from this tree, whereas eating from the tree of knowledge of good and evil was forbidden (2:16-17). After the human beings had eaten from the tree of knowledge of good and evil, they were not allowed to stay in the garden and to eat from the tree of life any more. Verse 3:22 shows that the tree of life should be understood as the tree of immortal life ('Yhwh God said, Now that the human being has become like one of us, knowing good and bad, what if he should stretch out his hand and take also from the tree of life and eat, and live forever!' - tr. EvW). In contrast, the tree of knowledge is closely related to sexuality and procreation, because the moment woman and man ate from this tree, they were said to have become aware of their nakedness ('they ate and their eyes were opened and they knew they were naked'-3:7), and to have felt the need to cover themselves. This is also confirmed by the fact that God, who was told by the first man that they were afraid to present themselves because they were naked, immediately concluded that this awareness was related to the tree of knowledge of good and evil (3:11). Thereupon God showed them the consequences of their actions: its positive effect was that they were now able to procreate and to have children; its negative effect - because they did transgress God's prohibition - was that childbearing would be painful for women and toiling the earth hard and painful for men. Eating from both trees would have granted the human couple both immortality and procreation, and these competences simultaneously would have been an impossible combination. ${ }^{31}$ That is why the human beings were sent out of the garden.

This being one of Genesis' predominant subjects, its main line of events (or plot) may be summarised as follows. The beginning and ending of the text concentrate on the relationship between the human being and the earth. At the text's beginning $(2: 5 \mathrm{a})$, the condition of the earth is characterised as 'not yet' filled with vegetation. The reasons for this are consequently given: it is 'because God had not let it rain on the earth, and there was no human being to till the soil' (2:5b). Then one of these two deficiencies is removed: a subterranean water comes up and moistens the whole surface of the ground (2:6). After a water supply has been arranged, and the earth is moistened, only the human being is missing. It is therefore still impossible for the earth to bring forth vegetation.

Against this backdrop, God forms the human being from dust of the earth and all that remains to be done, is to place this human being on the earth to cultivate it, which should

\footnotetext{
For a survey of various views of the narrative scenes, see Stordalen 2000:218-220.

Naidoff 1978; Vogels 1983; Van Wolde 1994.

Bechtel 1995 and Van Wolde 1994.

Mettinger 2007.

31 For an extensive description, see Van Wolde 1994:3-47; 1998:28-37.
} 
have been the end of the story. However, events take a different turn. God plants a garden in Eden and places the human being in this garden to till and protect it. As for the earth outside the garden, this as yet lies fallow: there is no tiller present and consequently there is no crop. For the time being the story continues inside the garden. Only in 3:17-24, at the story's ending, is the shortcoming described at the beginning removed. The earth receives the human being as its tiller: instead of the easy task of tilling and protecting the garden, the human being is now required to accomplish the much more arduous task of tilling the earth. ${ }^{32}$ The trees that grew independently in the garden of Eden are replaced by crops which are dependent on human attention. The relationship between human being and earth has developed throughout the story, it marks both the beginning and the end of the story, and is the framework in which the garden episode is laid. ${ }^{33}$

Subsequently the question arises why so much attention is paid to God's prohibition to eat from the tree of knowledge and to the relationship between man and woman. The necessity to differentiate the undivided human being, made out of the dust of the earth and entirely linked to the earth, is expressed by God in 2:18, where the woman is formed from the side of the human being. Once this is done, the human being, from being one and undifferentiated, has become differentiated and plural. In its relation with woman, אשה ('îshā), the human being no longer refers to itself as ('adām), that is, as a being differentiated from the אדמה ('adāmāa), but ash), as a being differentiated into man and woman (2:23). The human being turns out to be a relational creature: as a human being (s)he derives his or her identity from the relation with the earth, as a male human being he derives his identity in relation with a woman and as a female human being she derives her identity in relation with a man (cf. Vogels 1978).

In the beginning, this man and woman are very close, as is demonstrated by 2:25: 'They were both naked, but they did not feel ashamed.' But change comes soon. In the verse immediately following (3:1), the serpent is introduced as knowing or shrewd. The similarity between the words 'naked' ערומים ('ärümmîm) in 2:25 and 'knowing' ('ärüm) in 3:1 indicate a certain relatedness in content. ${ }^{34}$ This is confirmed in $3: 7$, for at the very moment woman and man eat from the tree of knowledge their eyes are opened, and they know that they are naked. The parallelism between 2:25 and 3:7 is obvious. Before the eating they were both naked and ignorant, after it they both know of their nakedness. They have acquired a discriminating power, and thus the necessary condition is fulfilled for sexual intercourse and procreation.

Consequently, in the primaeval history of Genesis, the story of paradise in chapters 2 and 3 specifies what was stated earlier in the story of creation in chapter 1, where God, in verses 26-28, created the human being as male and female and told them to be fruitful and multiply and fill the earth. All constituents of these verses in Genesis 1 return in Genesis 23: the relationship between the human being and the earth and the relationship between man and woman are specified, as well as their ability and obligation to multiply and spread over the earth.

32 This is clearly summarised in 3:23: 'So Yhwh God sent him/her from the garden of Eden, to till the earth from which (s)he was taken.'

33 In the last decades a growing number of authors have come to see the relation between human being and earth as at least one of the main themes of Gen 2-3. They include: Walsh 1977; Naidoff 1978; Vogels 1983; Van Wolde 1994; Stordalen 2000.

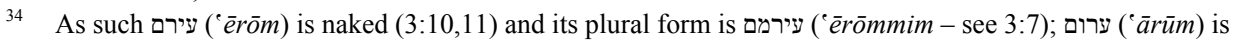

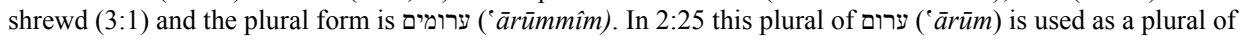
עירם ('érōm), to make a relation visible between naked and knowing or shrewd. 


\section{Timothy's Selection from Genesis 2-3}

After this sketch of Genesis 2-3 as a textual unit on its own, one may ask what the author of 1 Timothy 2:13-15 chose to select from this text. His main thesis seems to be that women are saved through childbearing. In order to support his thesis he refers to Genesis 2-3. His first argument is one of sequence: Adam was created first, then Eve. Based on this sequence, he apparently concludes that the best, that is Adam, comes first. However, this argument does not count in Genesis 1. Because there the human being was created last, and one usually concludes that the human being is the climax of creation. So, one may wonder why this conclusion is not valid for Eve. ${ }^{35}$ His second argument is that Eve was seduced, not Adam (1 Tim 2:14). Would it not have been more correct to say that Eve was seduced firstly and Adam secondly? And 1 Timothy's third argument is that Eve transgressed God's prohibition. We know, of course, that Adam did so, too. These three arguments are therefore not good examples of correct reasoning.

More important still is the following feature. In the story of Genesis 2-3 childbearing was the consequence of the transgression of the prohibition to eat from the tree of knowledge of good and evil. Because they were seduced and because they ate from the tree of knowledge, man and woman acquired the competence to procreate, and were thereby enabled to multiply and fill the earth. This is what makes 1 Timothy's argumentation so illogical. In 1 Timothy childbearing is presented as the woman's only route to salvation, yet at the same time the preceding activity that leads to childbearing, is rejected. And to support this, the author refers to Genesis! It is amazing! Nevertheless, the rhetorical strategy seems to have worked!

What is the 'mode of cognition' at work here? The author of 1 Timothy 2:13-15 employs a well-known story in ways that emphasise a strong cause and effect relation between a singular event in the story of the garden of Eden, and the present relation between men and women. 1 Timothy contrasts the thinking of Genesis 2-3, and by a limited selection of only two elements and a new embedding in his letter, the author is able to convey a new significance. Through this strategy he is able to change the way of thinking of contemporary and later audiences. The readers or hearers of 1 Timothy started to reread Genesis 2-3 with the text of 1 Timothy in mind. And they read in it a story of an evil woman transgressing God's prohibition and leading her husband astray. That is not what Genesis is about, but it does seem to be what 1 Timothy is about - at least as far as its history of interpretation was/is concerned. ${ }^{36}$

The letter written by 1 Timothy's author is, however, not only based on this employment of Genesis 2 and 3, but also on the way in which the debate is framed, so that it seems to assume that there is only one history and one story to be told. Indeed, 1 Timothy's rhetorical purpose seems to be to in some sense make this selection the audience's own. This is a letter in which recollection serves a normative prescription.

What then does the pairing of these highly selective and sharply contrasting citations suggest? It testifies of historical cognition that is partial, while depending on the subject of

\footnotetext{
35 See 1 Cor 11:7-9 where Paul also quotes from Gen 2, and even more selectively as he asserts that the man "is in the image and glory of God; but the woman is the glory of the man" (cf. Scholer 2003:111-115). Each time Paul seems to use data from the creation story selectively to suit the needs of the argument at hand, often as a warning against false teachings.

36 During its history of interpretation, Adam's status as 'first-created' and Eve's 'deception by the serpent' (even contra Rm 5:12-21), were often understood as confirming the superiority of men and the unsuitability of women for church leadership (Schottroff 1995:69-78; Webb 2001:263-268; Scholer 2003:111-115).
} 
1 Timothy's author. ${ }^{37}$ This probably explains why the authority of the writer of this document is stressed so emphatically: at the beginning and ending of his message he emphasises the truthfulness of his words, so that the audience will follow him in his reconstruction of the past, which very much depends on his present position. Therefore, the historical cognition also depends on the authority of Paul as the suggested writer of this letter. In addition, the evaluation of these words depends on the historical audiences. The letter of 1 Timothy helps the reading or hearing men to stick to their own highly valued positions, and provides them with ammunition to keep women in their rightfully defended inferior places. This may also explain why these words were so successful in their rhetorical effect, as ages of defenses of women's suppression in churches bear witness to, and which were often based on 1 Timothy $2 .^{38}$

\section{Reading 1 Timothy 2:8-15 Allegorically}

This leads us to conclude that, in spite of implied positive shifts, 1 Timothy's selective appropriation of the creation story is irreconcilable not only with its own theological thrust but also with that of Genesis 1-3. And yet, this was the hermeneutical position that prevailed for almost twenty centuries, legitimising the patriarchal status quo in many Christian communities. Could it thus be that a literal reading of 1 Timothy 2:13-15 does not account adequately for its enigmatic nature, and that further possibilities need to be explored?

At this point Paul Ricoeur's observation regarding the role of metaphorical language may be helpful. According to Ricoeur (1975:78), metaphor often opens up new meaning where a literal interpretation no longer makes sense.

In contrast to the predominantly literal interpretation of 1 Timothy 2:11-15 that prevailed for a long time, a dramatically different perspective was presented by Kenneth $\mathrm{L}$ Waters in an essay in Journal of Biblical Literature in 2004. Rather than reading it literally, Waters argued (2004:703-704) that the 'mode of cognition' of 1 Timothy 2:11-15 is that of an allegory or extended metaphor - a well-known method of interpretation at the time.

Waters refers to allegory as "language, imagery, and structure drawn from an ancient narrative and applied to a contemporary circumstance." ${ }^{39}$ He distinguishes the categories of typology and allegory by stating that "in a typology the present derives its meaning from the past, but in an allegory the past derives its meaning from the present" (2004:704; emphasis added). By drawing on Plato and Philo and their probable influence on earlier Ionian thinking and the symbolic world of Ephesus, Waters states that allegory connotes "a particular method of biblical interpretation contemporaneous with the Pastoral Epistles" (2004:703-710, cf. 722-727). In continuation with Alan Padgett and Andrew C Perriman, Waters argues extensively that the use of allegory in 1 Timothy 2 was determined by the

37 Some scholars have argued that the intended rhetorical effect of the references to Gen 2-3 in 1 Tim 2 could be that Eve's negative role was meant to serve as a cautionary type for those people in Ephesus who were prone to accept the deception of false teachings (cf. Wiebe 1994:60-61). In fact, they consider it probable that the author had the abuse of the Hebrew Scriptures (as part of the false teaching) in mind when referring to the creation and fall narratives of humankind. While such views would be coherent with the theological-ethical thrust of $1 \mathrm{Tim}$, it is not clear that this is what the author had in mind with 2:13-15.

38 One of the greatest hermeneutical challenges for biblical scholars is to ponder how the tension inherent in our own (often unquestioned ideological) pre-understandings of a text may correlate with the tensions within the text itself, as well as the socio-historical situation of the early faith communities by which it was prompted. This is particularly pertinent to the study of 1 Tim 2:8-15, which has become almost embarrassing in the attention it draws to itself, out of all proportion to its exegetical significance (Porter 1993:87-88). For an extended bibliography on the passage see Mounce 2000:94-102.

39 According to Deist (1990:8), allegory may be defined as "a literary device, and even a literary genre, that makes extensive use of figurative or symbolic language to expound a subject or to tell a story." 
present (rhetorical) situation of the author and his audience, and "that there is nothing idiosyncratic about the author's hermeneutic in 1 Tim 2:11-15" (2004:705). For Waters, "(r)ecognition of the allegorical character of 1 Tim 2:11-15 is forced by the author's appropriation of Gen 3:1-21, particularly his use of the names Adam and Eve" (2004:708). Accordingly:

(a)s Adam was 'formed first' ( $\left.\pi \rho \hat{\omega} \tau 0 \varsigma \epsilon^{\prime} \epsilon \pi \lambda \dot{\alpha} \sigma \theta \eta\right)$ in Gen 2:7-25, so the male teachers and leaders of the Ephesian church were formed first in Christ before the women. The seniority of the male teachers and leaders in Christ becomes the author's reason for affirming their authority over those women of Ephesus who were far less mature in terms of their Christian development (not the authority of every man over every woman). It was because of their immaturity in Christ that these women were being deceived by false teachers, just as Eve was deceived by the serpent. They were therefore called on to submit in silence to the instruction of more seasoned, genuine leaders (Waters 2004:709-710).

In Waters' view, the allegorical character of 1 Tim 2:11-15 is further recognisable by the apparent equivalence the author created between the singular pronoun 'she' and the plural

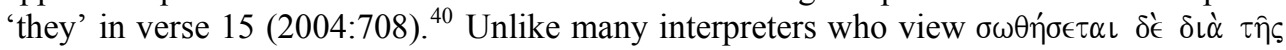
$\tau \in \kappa \nu O \gamma o \nu i \alpha \varsigma$ in 2:15 as referring to the literal act of childbearing (which would be at odds with the rest of Pauline thinking about salvation), Waters shows how the immediate and larger literary context of the passage, as well as the symbolic world of Greek mythology and Hellenistic thinking, created a nonliteral, metaphorical equivalence between children and the virtues of faith, love, holiness, and temperance (2004:710-727; cf. Solevåg 2011:106-107). ${ }^{41}$ According to Waters:

(such) a reading would have been a natural, although metaphorical, interpretation of good works (' $\rho^{\prime} \gamma \alpha \alpha \dot{\alpha} \gamma \alpha \theta \dot{\alpha}$ ) for women in 1 Tim 2:10. Oddly, we probably would have been spared years of modern exegetical difficulty if the author of 1 Timothy had used the term "fruit bearing" instead of 'childbearing' in 2:15 ... However ... the most prevalent metaphorical use of children in the cultural environment of the Pastoral Epistles was as references to virtues. The author ... therefore uses his audience's familiarity with a commonplace idea to introduce a more Christian form of that same idea (Waters 2004:715-716). ${ }^{42}$

40 The tenses of the verbs in 2:15 shift from the singular future ( $\sigma \omega \theta \eta \dot{\sigma} \sigma \tau \alpha \iota$ - from Eve's restored perspective?)

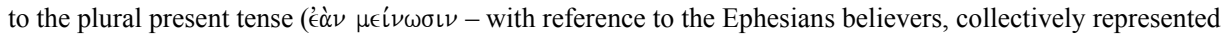
by Eve?). The grammar of the argument is probably as complex as the analogy between Eve and (the Ephesians?) women (and men?) itself (cf. Porter 1993; Wall 2004:93-99). However, the underlying moral theme of the letter becomes evident once again. Believing, praying women and men in Ephesus would be bearers of life, co-saviours with Christ Jesus, "provided they continue in faith and love and holiness, with modesty." This is probably the reliable saying to which 3:1 was meant to refer. At the same time this creates the possibility that 1 Timothy's interpretation of Gen 2-3 could have been a "calculated error" (Ricoeur 1975:78) - a deliberate effort on the author's part to force his audience to give new (metaphorical) meaning to traditional concepts which no longer made (literal) sense.

41 Socrates (being the son of a midwife) was known for regarding himself a midwife for the souls of 'men' (Waters 2004:726).

42 The example of childbearing could have been chosen because the false teachers were downplaying the importance of marriage ( 1 Tim 4:1-5; cf. 3:2,4,12; 5:14). Generally, for women to be childbearers in the patriarchal Greco-Roman culture of the first century, would have been a primary way of embodying the cardinal virtue of $\sigma \omega \phi \rho \circ \sigma u ́ \nu \eta$ (modesty, decency, sobriety, sound moral judgment, discretion, prudence or good sense - cf. Johnson 2001:200,203; Brown 1992:80-93; Wall 2004:86; Solevåg 2011:51-53). It would have been in harmony with the religious views of Asia Minor and especially Ephesus where the maternal

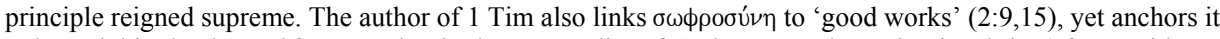
- through his theological framework - in the new reality of God's restored creation in Christ (cf. 3:2 with respect also to male leaders). The link between salvation and childbirth (both metaphors for new life) could thus have served as a piece of concrete advice against the opponents' ascetic teachings, which the author 
An allegorical reading of 1 Timothy 2:11-15 (re-)opens the possibility that references to Adam and Eve, as well as the image of childbearing, functioned metaphorically to encourage life-giving behaviour amidst false teachings at the time. There is, however, no guarantee that such rhetoric would have produced a counter-cultural interpretation of Genesis 2-3. Allegory as sense-making of the past in view of the (patriarchal) present runs the risk of endorsing a hierarchical interpretation of the creation story similar to that of a literal reading. The reason for this is that both the transformative potential and risk of metaphor lies in its reference. If the 'new' in its reference is not recognisable to an audience, it will not shock or surprise, but (unwittingly) support the status quo. ${ }^{43}$

\section{Timothy 2 - 'Clay Jar' of Human Interpretation?}

Where does this leave us? Did the author of this (pastoral!) epistle after all find himself caught up in the tensions and terrors of a theologically liberated yet culturally limited liturgical-social space (Johnson 2001:206-211; Schneiders 1989)? While author and recipients were called to fight the good fight against any form of unworthy behaviour (including any form of partiality or favouritism - 5:21), the author's selective use of the creation story nevertheless seems to have jeopardised its transformative power for later audiences in unthinkable ways. As such 1 Timothy witnesses to the fragile reality that the gospel was entrusted to human beings - a 'treasure in clay jars' (1:11; 6:20; 2 Cor 4:7).

Biblical scholars, systematic and pastoral theologians, and preachers all share the creative yet complex liminal space between the (for Christians) 'authoritative' witness of 1 Timothy and the experiences (of alienation, disillusion, confusion) of present-day audiences. We therefore suggest that 1 Timothy 2 be regarded as resembling the dynamic processes through which the early faith communities wrestled to understand the will of God for their particular time, while using available language and metaphors from their contexts. Whether viewed literally or allegorically, it should at least be clear that 1 Timothy 2:8-15 functioned as a context-specific appropriation of the creation story (albeit strange from our point of view), and not as a universal statement on human dignity, or a moral prescription for all times and places.

Yet, how do we respect the text as a product of its time and at the same time allow it to inform and transform our own rhetoric and praxis, so that the integrity of God's justiceseeking new creation in Christ Jesus will likewise be recognised by all? We conclude that re-reading this text (in Africa today) may challenge and liberate us in at least two ways:

rebuts by insisting on the goodness of God's creation. From such a perspective, one might argue that women's calling to be life-givers - physically and/or metaphorically (cf. Gen 3:20) - is being affirmed here. No wonder that some interpreters consider that the text refers to Mary, the mother of Jesus, who - unlike Eve - presented the world with the Saviour, the new Adam (cf. Wall 2004:95-96). In this sense 2:15 can be seen as radically contrasting Eve and all believing women the 'snake of deception' - both in the creation narrative of Gen 2-3 and the Ephesians community (cf. Kroeger \& Kroeger 1992:117-177 for a discussion of the many perspectives on Eve and the serpent in ancient myths; Fuhrmann 2010:31-46; Solevåg 2011:60-74, 244-245 for interpretations of 2:15 against the backdrop of ancient medical teachings concerning female diseases and Greco-Roman, gnostic and early Christian writings related to myths of the 'womb' and the topos of 'salvation').

43 Reading 1 Tim 2:11-15 allegorically would obviously have implications for interpreting the rest of the Pastorals. If we as later readers read 1 Timothy's interpretation of Gen 2-3 allegorically, what about other parts of 1 Timothy - such as 6:1-2, "Let all who are under the yoke of slavery regard their masters as worthy of all honour, so that the name of God and the teaching may not be blasphemed..."? And what about the "gains" for women in 1 Tim 2:9,11? Since all theological language is metaphorical in nature, its use and moral appropriation would necessarily need to be congruent with believers' (liberating, community-creating) faith in God and Jesus Christ and the discernment of God's Spirit, and thus be accountable as trustworthy to all members of the faith community (cf. 1 Tim 4:9-10; Hays 1996:66-72). 
- by using its explicit theological thrust as a rhetorical lens to boldly read against its patriarchal grain and history of reception, while allowing the text to speak afresh in its full (con)textuality;

- or by accepting the text (at least in some respects) as irretrievably patriarchal and 'violent' (Desjardins 1997:99-100) without saving it theologically, yet allowing it to function as a mirror for on-going discussions on human dignity and the integrity of creation.

Both positions may express an honest yearning to be faithful to the 'authority' of the bible (as freedom, participation and community - Russell 1987:43-57). Both would nevertheless need careful discernment. In continuation with the dynamic processes represented by it, 1 Timothy 2 invites and stimulates an ongoing, faithful struggle to interpret God's radical presence in the world. Anything less would run the risk of being incompatible with the rich world of discipleship that the bible projects, and of confining a living God to the boundaries of an ancient text in ways contradictory to its theological thrust.

\section{BIBLIOGRAPHY}

Bassler, JM 2000. 1 Timothy, in Mays, JL (general ed.), Harper Collins Bible Commentary. Rev ed. San Francisco: HarperSanFrancisco, 1137-1141.

Barnett, PW 1989. Wives and Women's Ministry (1 Timothy 2:11-15). Evangelical Quarterly 61/3, 225-238.

Bediako, K 2000. Jesus in Africa: The Christian Gospel in African History and Experience. Akropong-Akuapem: Regnum Africa.

Bowman, AL 1992. Women in Ministry: An Exegetical Study of 1 Timothy 2:11-15. Bibliotheca Sacra 149, 193-213.

Brooten, BJ 1986. Jewish Women's History in the Roman Period: A Task for Christian Theology, in Nickelsburg, GWE \& MacRae, GW (eds.), Christians among Jews and Gentiles: Essays in honor of Krister Stendahl on his sixty-fifth birthday, 22-30. Philadelphia: Fortress.

Brown, LA 1992. Ascetism and Ideology: The Language of Power in the Pastoral Epistles. Semeia 57, 77-94.

Cotter, W 1994. Women's Authority Roles in Paul's Churches: Counter-culture or Conventional? Novum Testamentum 36, 350-72.

Deist, F 1990. A Concise Dictionary of Theological and Related Terms. Pretoria: JL van Schaik.

Desjardins, M 1997. Peace, Violence and the New Testament. Sheffield: Sheffield Academic Press.

Dewey, J 1998. 1 Timothy, in Newsom, CA \& Ringe, SH (eds.), Women's Bible Commentary. Expanded (ed.), 444-449. Louisville: Westminster John Knox.

Donelson, LR 1988. The Structure of Ethical Argument in the Pastorals. Biblical Theology Bulletin 18/3, 108-113.

Ferguson, E 2003. Backgrounds of Early Christianity. 3rd ed. Grand Rapids: Wm B Eerdmans.

Fuhrmann, S 2010. Saved by childbirth: Struggling ideologies, the female body and a placing of 1 Tim 2:15a. Neotestamentica 44/1, 31-46. 
Gritz, SH 1991. Paul, Women Teachers, and the Mother Goddess at Ephesus: A Study of

1 Timothy 2:9-15 in Light of the Religious and Cultural Milieu of the First Century.

Lanham/New York: University Press of America.

Hays, RB 1996. The Moral Vision of the New Testament: Community, Cross,

New Creation. New York: HarperSanFrancisco.

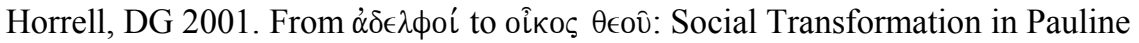
Christianity. JBL 120/2, 293-311.

Jacobs, M 2002. Vroue en die Nuwe Hervorming: Afskeid van die Pastor, in Muller, P (red.), Die Nuwe Hervorming, 112-133. Pretoria: Protea Boekhuis.

Johnson, LT 2001. The First and Second Letters to Timothy. (Anchor Bible 35A).

New York: Doubleday.

Kanyoro, MRA \& Njoroge, NJ (eds.) 1996. Groaning in Faith: African Women in the Household of God. Nairobi: Acton.

Kawale, WR 2001a. The role of women in social transformation in the Nkhoma Synod (Malawi). Scriptura 77, 211-223.

_ 2001b. Women, social transformation and the Bible in Nkhoma Synod (Malawi). Scriptura 77, 225-238.

Keener, CS 1992. Paul, Women and Wives: Marriage and Women's Ministry in the Letters of Paul. Peabody: Hendrickson.

Kittredge, CB 1998. Community and Authority: The Rhetoric of Obedience in the Pauline Tradition. Harrisburg: Trinity.

Kroeger, RC \& Kroeger, CC 1992. I Suffer Not a Woman: Rethinking 1 Timothy 2:11-15 in light of ancient evidence. Grand Rapids: Baker Book House.

Malina, BJ 1993. The New Testament world: Insights from cultural anthropology. Rev ed. Louisville: Westminster.

Meeks, WA 1983. The First Urban Christians: The Social World of the Apostle Paul. New Haven: Yale University.

— 1993. The Origins of Christian Morality: The First Two Centuries. New Haven: Yale University.

Mettinger, TND 2007. The Eden Narrative: A Literary and Religio-historical Study of Genesis 2-3. Winona Lake (Ind): Eisenbrauns.

Mounce, WD 2000. Pastoral Epistles. (Word Biblical Commentary 46). Nashville: Thomas Nelson.

Mouton, E 2002. Reading a New Testament Document Ethically. Atlanta: SBL/Leiden: Brill.

_ 2006. Van Eden naar Heden via Paulus, in Van Wolde, E (red), Het paradijs, 73-89. Zoetermeer: Meinema.

_ 2011. Human dignity as expression of God images? Perspectives from/on 1 Corinthians 14 and Ephesians 5. Neotestamentica 45/2, 275-292.

— 2012. Reading a pastoral 'text of terror' in Africa today? 1 Timothy 2:8-15 as a context-specific appropriation of the creation story, in Hendriks, HJ, Mouton, E, Hansen, L, Le Roux, E (eds.), Men in the Pulpit, Women in the Pew? Addressing gender inequality in Africa, 115-128. Stellenbosch: SUN MeDIA.

Naidoff, BP 1978. A Man to Work the Soil: A New Interpretation of Genesis 2-3. ISOT 5, 2-14. 
Newsom, CA 2006. Rhyme and Reason: The Historical Résumé in Israelite and Early Jewish Thought, in Lemaire, A (ed.), Papers of the IOSOT Conference Leiden 2004 (Vetus Testamentum Suppl. 109), 215-233. Leiden: Brill.

Oduyoye, MA 2002. Beads and Strands: Reflections of an African woman on Christianity in Africa. Akropong-Akuapem: Regnum Africa.

Osiek, C 1996. The family in Early Christianity: 'Family Values' Revisited. $C B Q 58 / 1,1-24$.

— 2005. Family Matters, in Horsley, RA (ed.). Christian Origins, 201-220. Minneapolis: Fortress.

Pelser, GMM 1984. Die Pastorale briewe, in Du Toit, AB (red.), Die Pauliniese Briewe: Inleiding en Teologie (Handleiding by die NT, Vol V), 174-196. Pretoria: NG Kerkboekhandel Tvl.

Phiri, IA 2000. African women in mission: Two case studies from Malawi. Missionalia 28, 267-293.

Porter, SE 1993. What does it mean to be 'saved by childbirth' (1 Timothy 2.15)? JSNT 49, 87-102.

Ricoeur, P 1975. Biblical hermeneutics. Semeia 4, 29-148.

Roloff, J 1988. Der erste Brief an Timotheus. Zürich: Benziger Verlag.

Russell, LM 1987. Household of Freedom: Authority in Feminist Theology. Philadelphia: Westminster.

Sanders, JA 2002. The Family in the Bible. Biblical Theology Bulletin 32/3, 117-128.

Schneiders, SM 1989. Feminist ideology criticism and biblical hermeneutics. Biblical Theology Bulletin 19, 3-10.

— 1995. Feminist Hermeneutics, in Green, JB (ed.), Hearing the New Testament:

Strategies for Interpretation, 349-369. Grand Rapids: Wm B Eerdmans.

Scholer, D 2003. 1 Timothy 2.9-15 and the Place of Women in the Church's Ministry, in Levine, A-J \& Blickenstaff, M (eds), A Feminist Companion to the Deutero-Pauline Epistles, 98-121. Cleveland: The Pilgrim Press.

Schüssler Fiorenza, E 1999. Rhetoric and Ethic: The Politics of Biblical Studies. Minneapolis: Fortress.

Schottroff, L 1995. Lydia's Impatient Sisters: A Feminist Social History of Early Christianity (tr. B \& M Rumscheidt). London: Westminster John Knox.

Solevåg, AR 2011. Birthing Salvation: Childbearing and Salvation in Early Christian Discourse. PhD dissertation, University of Oslo.

Stordalen, T 2000. Echoes of Eden: Genesis 2-3 and Symbolism of the Eden Garden in Biblical Hebrew Literature. Leuven: Peeters.

Trible, P 1984. Texts of Terror: Literary-Feminist Readings of Biblical Narratives. Philadelphia: Fortress.

Vogels, W 1978. It is not good that the 'Mensch' should be alone; I will make him/her a helper fit for him/her (Gen 2,18). Eglise et Théologie 9, 9-35.

— 1983. L'être appartient au sol. Gen 2,4b-3,24. Nouvelle Revue Théologique 105, 515-534.

Wall, RW 2004. 1 Timothy 2:9-10 Reconsidered (Again). Bulletin for Biblical Research 14.1, 81-103. 
Walsh, JT 1977. Genesis 2:4b-3:24: A Synchronic Approach. JBL 96/2, 161-177.

Waters, KL 2004. Saved through childbearing: Virtues as children in 1 Timothy 2:11-15. JBL 123/4, 703-735.

Webb, WJ 2001. Slaves, Women \& Homosexuals: Exploring the Hermeneutics of Cultural Analysis. Downers Grove: Intervarsity Press.

West, G 2004. Taming Texts of Terror: Reading (against) the Gender Grain of 1 Timothy. Scriptura 86/2, 160-173.

Wiebe, B 1994. Two texts on women (1 Tim 2:11-15; Gal 3:26-29) a test of Interpretation. Horizons in Biblical Theology 16/1: 54-85.

Wolde, EJ van 1994. Words become Worlds: Semantic Studies of Genesis 1-11. (Biblical Interpretation 6). Leiden: Brill.

- 1998. Facing the Earth: Primaeval History in a New Perspective, in Davies, PR \& Clines, DJA (eds.), The World of Genesis: Persons, Places, Perspectives (ISOTS 257), 22-47. Sheffield: Sheffield Academic Press.

- 2006. Het paradijsverhaal in Genesis 2-3, in Van Wolde, E (red.), Het paradijs, 9-32. Zoetermeer: Meinema. (Serie: De bijbel: teksten en thema's in beeld.) 


\section{ADDENDUM A - 1 Tim 1:15-3:1 (NA27)}

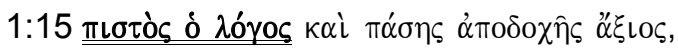

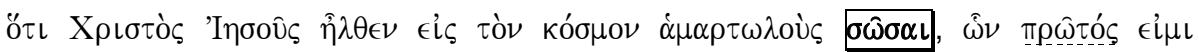
'€үต́.

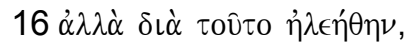

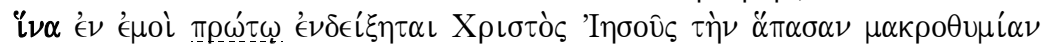

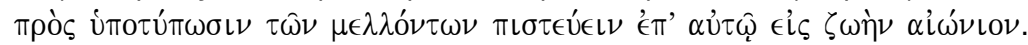

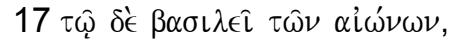

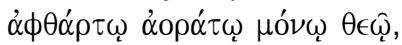

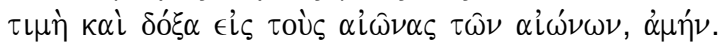

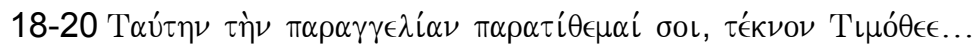

2:1 П

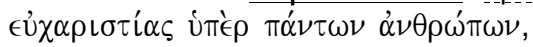

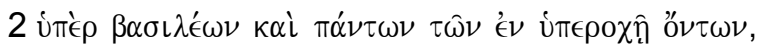

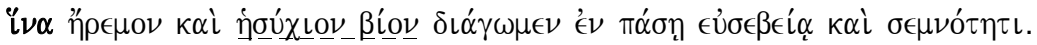

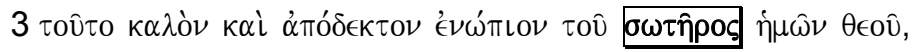

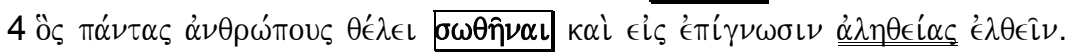

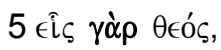

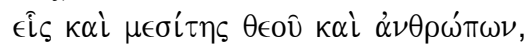

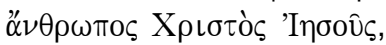

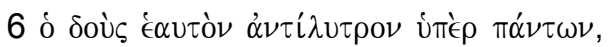

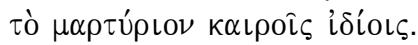

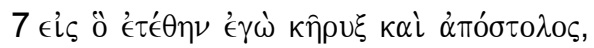

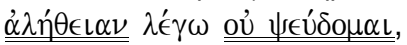

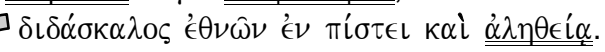

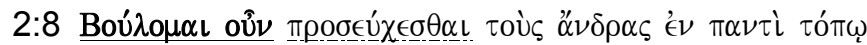

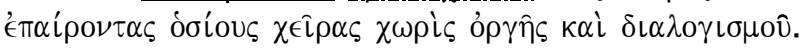

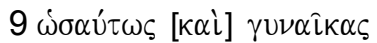

$\epsilon \nu \kappa \alpha \tau \alpha \sigma \tau 0 \lambda \hat{n} \kappa о \sigma \mu i \omega$

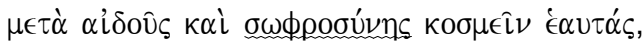

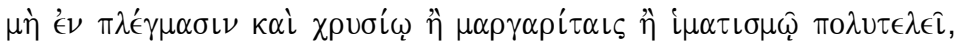

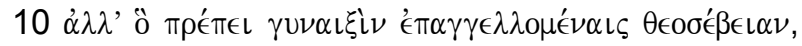

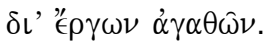

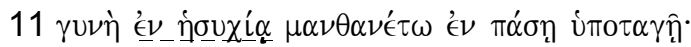

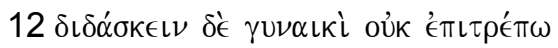

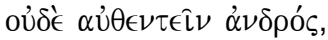

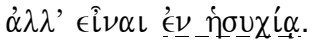

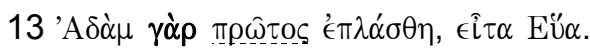

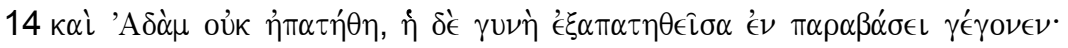

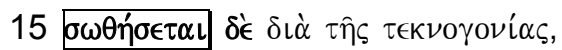

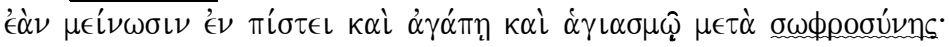

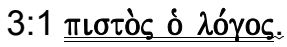

